\title{
The Effect of Milk or its Combination with Tea and $0.2 \%$ NaF on Dental Enamel Demineralization Analyzed by Micro Computed Tomography
}

\author{
Anton Rahardjo ${ }^{1}$, Raisa D. Sahertian ${ }^{2}$, Siti A. Ramadhani ${ }^{2}$, Diah A. Maharani ${ }^{1}$, Fourier \\ DE. Latief ${ }^{3}$ \\ ${ }^{1}$ Department of Preventive and Public Health Dentistry, Faculty of Dentistry, University of Indonesia, \\ Jakarta 10430, Indonesia \\ ${ }^{2}$ Undergraduate Program, Faculty of Dentistry, University of Indonesia, Jakarta 10430, Indonesia \\ ${ }^{3}$ Laboratory of Earth Physics and Complex Systems, Physics Study Program Building, Institute Technology \\ of Bandung, Bandung 40132, Indonesia \\ Corresponding e-mail to: antonrahardjo@gmail.com
}

\begin{abstract}
Fluoride and calcium play an important role in the prevention of dental caries, promoting the inhibition of demineralization and the increase of remineralization. Objective: To investigate the effects of milk with/without the combination of tea and $0.2 \% \mathrm{NaF}$ on enamel demineralization using micro-computed tomography (microCT). Methods: The coronal parts of 40 extracted sound premolars were prepared as tooth blocks. An unvarnished occlusal surface window was created for each tooth by covering the occlusal surface with a $3 \times 5 \mathrm{~mm}^{2}$ sticker and painting all other surfaces with an acid-resistant varnish. These blocks were randomly allocated into four groups that were immersed in remineralizing solutions for 26 minutes: Group A, milk; Group B, milk and tea; Group C, milk and $0.2 \% \mathrm{NaF}$; and Group D, deionized water (control). Results: After 3 days of immersion in a buffered demineralization solution at $\mathrm{pH} 4.4$, micro-CT scans were taken. The mean grayscale values and the standard deviations are: $98.1 \pm 24.0 ; 90.8 \pm 9.1 ; 92.6 \pm 21.4 ; 81.1 \pm 20.3$, respectively. The mean grayscale values were significantly different among the four groups $(p<0.05)$, except between groups A and B and between groups A and C. Conclusion: Topical application with milk alone showed a higher protective effect against demineralization compared to the synergic application of milk and tea and milk and $0.2 \% \mathrm{NaF}$.
\end{abstract}

\begin{abstract}
ABSTRAK
Efek susu, kombinasinya dengan teh, dan NaF 0,2\% terhadap demineralisasi email gigi: analisis microcomputed tomography. Fluor dan kalsium berperan penting dalam pencegahan karies gigi, karena dapat menghambat demineralisasi dan meningkatkan remineralisasi Tujuan: Menganalisis efek dari susu sendiri dan kombinasi dengan teh, dan $\mathrm{NaF}$ 0,2\% pada demineralisasi email gigi menggunakan micro-computed tomography (micro-CT). Metode: Pada bagian koronal 40 gigi premolar manusia yang telah diekstraksi, dibuatkan region of interest. Permukaan oklusal tiap gigi tersebut ditutupi stiker $3 \times 5 \mathrm{~mm}^{2}$ dan semua permukaan lainnya ditutupi dengan pernis tahan asam. Gigi-gigi yang telah dipersiapkan ini secara acak dan dialokasikan ke dalam empat kelompok yang direndam dalam larutan remineralisasi selama 26 menit, yakni: Grup A, susu; Grup B, susu dan teh; Grup C, susu dan NaF 0,2\%; dan Grup D, deionized air (kontrol). Hasil: Setelah 3 hari perendaman dalam larutan buffer pada $\mathrm{pH} 4,4$, dilakukan pemindaian dengan micro-CT. Nilai rata-rata grayscale dan standar deviasi secara berurutan: $98,1 \pm 24,0 ; 90,8 \pm 9,1 ; 92,6 \pm 21,4 ; 81,1 \pm 20,3$. Nilai rata-rata grayscale yang berbeda bermakna secara signifikan antara empat kelompok tersebut $(p<0,05)$, kecuali antara kelompok A dan B dan antara kelompok A dan C. Simpulan: Topikal aplikasi dengan susu saja menunjukkan efek perlindungan yang lebih tinggi terhadap demineralisasi dibandingkan dengan aplikasi sinergis susu dengan teh dan, susu dengan, $0,2 \% \mathrm{NaF}$.
\end{abstract}

Key words: demineralization, dental enamel, micro-computed tomography 


\section{INTRODUCTION}

Inequality in dental care in Indonesia persisted from 1999 to 2009, with an average of unmet dental care need in 2003-2007 of 72.04\%. ${ }^{1,2}$ This could be an indicator that the current implementation of Indonesia's dental health policy is not effective, such as the implementation of the school-based dental program. Previous studies assessed the effectiveness of the Indonesian school-based dental program in controlling caries, which suggested that the Decayed Missing Filling Teeth (DMF-T) scores of children were related to social factors rather than to oral health service activities in the school program., Therefore, an intervention program that is applicable, effective, feasible, sustainable and acceptable by the Indonesian community is urgently required.

Access to oral health services is limited, and a significant amount of the population is underserved. ${ }^{5}$ For these reasons, professionally applied fluoride is less relevant than for populations who receive regular dental care. ${ }^{6}$ An alternative is to use products that are consumed daily by the community, such as milk and tea. Evidence of the success of milk fluoridation as a public health measure has been shown in a wealth of studies. ${ }^{7-9}$ Tea has also been widely studied for its fluoride content and effectiveness in preventing dental caries. ${ }^{10}$ Nonetheless, fears regarding the systemic use and effect of fluoride still arise in the community, therefore the topical application of fluoride would be more acceptable in the community. ${ }^{11}$ Thus, evidencebased topical application of daily dairy and topical use of fluoride shall be explored in Indonesia.

The concentration of $0.05 \%, 0.2 \%$ and $0.5 \%$ are the recomended sodium fluoride to be used for gargling daily, weekly and monthly for high caries risk. ${ }^{12}$ Thus, there has been substantial public and professional debate about fluoride, and myriad information is available, often with confusing or conflicting messages. ${ }^{12}$ Therefore this study explored other alternatives for subsitution of fluoride alone. Previous study demonstrated that calcium contained in yogurt, which are daily comsumed by Australian, have an inhibitory effect on demineralization and promote the remineralization of dental enamel. ${ }^{13}$ Moreover, a study evaluated the efficacy of calcium used alone or with fluoride as compared to fluoride mouth rinse for the remineralisation of occlusal white spot lesions in an in vivo pilot study. It was revealed that the remineralising potential of calcium $+0.2 \% \mathrm{NaF}$ and calcium alone were similar, however, both groups were superior to $0.5 \% \mathrm{NaF}$ mouthrinse. Calcium is highly beneficial for the remineralisation of non-cavitated occlusal white spot lesions when compared to $0.5 \% \mathrm{NaF}$ mouthrinse. ${ }^{14}$ Subsequently, this study explored the potential of calcium and fluoride containing beverages such as tea and milk, which are common in Indonesian community and would be feasible intervention to be adapted.
Micro-computed tomography (micro-CT) provides high-resolution three-dimensional (3D) digital images through non-destructive scanning. ${ }^{15}$ The scan images can be used for qualitative and/or quantitative evaluation and analysis. Micro-CT is a reliable method for detecting density changes in enamel lesions after remineralization and demineralization. ${ }^{16}$ The aim of this study was to use micro-CT to investigate the effects of milk alone, the synergistic effects of milk and tea, and the synergistic effects of milk and $\mathrm{NaF}$ on the demineralization of enamel in vitro.

\section{METHODS}

Forty permanent premolar teeth were selected from a pool of extracted teeth. The criteria for selection were that each tooth had no restorations, intact crowns and no defects or caries. Each root was cut off from the tooth, resulting an intact crown. Then, each crown was cut into a $6 \mathrm{~cm}^{3}$ block. An unvarnished occlusal surface window was created for each of these 40 tooth blocks by covering each occlusal surface with a $3 \times 5$ $\mathrm{mm}^{2}$ sticker and painting all other surfaces with an acid-resistant varnish. ${ }^{17}$ These blocks were randomly allocated into four groups that were immersed in remineralizing solutions for 26 minutes at $37^{\circ} \mathrm{C}$ : Group A, milk; Group B, milk and tea; Group C, milk and $0.2 \% \mathrm{NaF}$; and Group $\mathrm{D}$, deionized water (control). Next, the tooth blocks were immersed in a buffered demineralization solution at $\mathrm{pH} 4.4$ for 3 days. A 10-minute wash in deionized water was performed between the remineralization and demineralization phase and at the end of the process.

A Skyscan Scanner 1173 (Skyscan Company, Antwerp, Belgium) desktop micro-CT was used to scan the tooth blocks. We fabricated a custom attachment from dental wax for the teeth to fit in the specimen holder of the micro-CT unit. The micro-CT x-ray source was set at $100 \mathrm{kV}$ and $80 \mu \mathrm{A}$. The scanning results were reconstructed using NRecon software (Skyscan Company, Antwerp, Belgium) and then analyzed using CTAn (Skyscan Company, Antwerp, Belgium). From the reconstructed $3 \mathrm{D}$ images of the lesion on each tooth block, 20 images were selected by systematic random sampling. The demineralized lesions in these 20 images were considered the region of interest and were chosen to represent the whole lesion body of that particular window. Regarding the mineral loss data, factorial analysis of variance (ANOVA) was used to assess the effects of the remineralization solutions in preventing enamel demineralization.

\section{RESULTS}

After demineralization, visual examination revealed that there were demineralization lesions, opaque white areas, on the tooth blocks. Demineralization 
Table 1. Mean enamel greyscale value after intervention

\begin{tabular}{lc}
\hline Intervention materials & $\begin{array}{c}\text { Mean Greyscale } \\
\text { Value } \pm \text { SD }\end{array}$ \\
\hline Group A (milk) & $98.1 \pm 24.0$ \\
Group B (milk and tea) & $90.8 \pm 19.1$ \\
Group C (milk and 0.2\% NaF) & $92.6 \pm 21.4$ \\
Group D (deionized water / & $81.1 \pm 20.3$ \\
control) & \\
\hline
\end{tabular}

Table 2. ANOVA results between groups of experiments

\begin{tabular}{|c|c|c|}
\hline milk (A) & $\begin{array}{l}\text { milk and tea } \\
\text { (B) }\end{array}$ & $\begin{array}{c}\text { milk and } 0.2 \% \\
\mathrm{NaF}(\mathrm{C})\end{array}$ \\
\hline $\begin{array}{l}\text { deionized water / Significant } \\
\text { control (D) }\end{array}$ & Significant & Significant \\
\hline milk (A) & Not Significant & Not Significant \\
\hline milk and tea (B) & & Significant \\
\hline
\end{tabular}

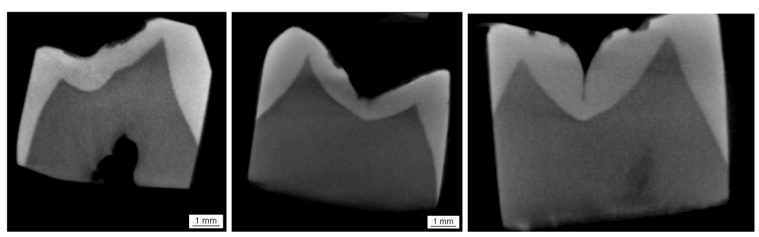

Figure 1. Micro CT Specimen scan results by Micro CT, showing demineralization lesion on the coronal region of intersest

lesions could be easily observed in the 3D images of all of the tooth blocks (Figure 1). The mean grayscale values and standard deviations in the occlusal window areas of the tooth blocks in Group A (milk); Group B (milk and tea); Group C (milk and 0.2\% NaF); and Group D (deionized water /control) were 98.1 \pm 24.0 ; $90.8 \pm 19.1 ; 92.6 \pm 21.4 ; 81.1 \pm 20.3$, respectively (Table 1). Among the four groups, the mean grayscale values were significantly different $(p<0.05)$ except between groups $\mathrm{A}$ and $\mathrm{B}$ and between groups $\mathrm{A}$ and $\mathrm{C}$ (Table 2). The synergistic effects in promoting the inhibition of demineralization and the increase of remineralization of milk with tea and milk with $0.2 \% \mathrm{NaF}$ were relatively small. The application of milk alone showed higher potential in inhibitting demineralization compared to the application of milk and tea and milk and $0.2 \% \mathrm{NaF}$.

\section{DISCUSSION}

This study explored the potential of calcium and fluoride containing beverages such as tea and milk, which are common in Indonesian community and would be feasible intervention to be adapted. Micro CT analysis were employed to evaluate the invitro intervensions. The in vitro assay did not attempt to prevent tooth demineralization, instead, this study aims were to analyze the effect of milk, tea and $0.2 \%$ $\mathrm{NaF}$ on dental enamel mineralization. A milk gargling campaign could be a joint action of communities, professionals and individuals aimed at reducing the prevalence of dental caries. This study also suggests a sound scientific basis for the topical use of milk to prevent caries and provides support for the safety of this product, which had been analyzed previously. ${ }^{7,8,18}$

A limitation of study arose due to the unknown information regarding the age of the subjects whose teeth were extracted and used in this study. This variable could affect the structure of the tooth and cause different effects on the intervention made in this study. ${ }^{19}$ Despite this limitation, the randomization of the samples decreases the potential for biases. Further, only the effects of milk and its combined use with tea and $0.2 \% \mathrm{NaF}$ on enamel demineralization were investigated in this study. Nonetheless, this findings contribute to understanding topical application, which determined there is no demineralization effect when milk or respective conjugate (tea or $0.2 \% \mathrm{NaF}$ ) were present on tested dental enamel surfaces. Further studies on the effects of tea alone and $0.2 \% \mathrm{NaF}$ alone on tooth blocks undergoing a $\mathrm{pH}$-cycling challenge or a bacterial challenge in an artificial mouth model should be conducted using micro-CT scanning, which allows for the non-destructive study of tooth blocks, to better understand each specific role that may be played by these interventions in the caries development process. Moreover, there is a technical problem with the method used in this study when assessing lesions in pit and fissure areas because they have irregular surface borders. ${ }^{17}$ The difficulties lie in drawing the region of interest properly and in measuring the path length of the irregular lesion surface border accurately. ${ }^{17}$

Nonetheless, the data from the present study clearly showed that micro-CT offers a reproducible, noninvasive technique for the $3 \mathrm{D}$ assessment of demineralization and remineralization of dental enamel. Because micro-CT is nondestructive approach, it is possible to analyze the mineralization of dental enamel before, during and after $\mathrm{pH}$ cycling. Internal and external tooth anatomy can be shown simultaneously or separately. ${ }^{20}$ A significant amount of information can be gleaned from the scans, and slices can be recreated in any plane, while the data can be presented in $2 \mathrm{D}$ or $3 \mathrm{D}$ images. ${ }^{20}$ Therefore, micro-CT can be a powerful tool for research in dentistry and can also be widely used in preventive dentistry research. ${ }^{21}$

\section{CONCLUSION}

Although limitations occured in this research, it is suggested that milk has higher potential in supporting dental enamel remineralization. In addition this study aimed was the effect, and not the inhibition ability of dental enamel demineralization. The use of tea and $0.2 \%$ $\mathrm{NaF}$ after intervene of milk to optimize dental enamel remineralization was not proven by this research. Milk 
alone has high potential in supporting remineralization. Tea which contain calcium and is a common bevarage in Indonesia might robust the effectivenes of milk in dental enamel remineralization as well as $0.2 \% \mathrm{NaF}$. But this research showed that gargling milk alone could be use to inhibit demineralization. Fluoride and calcium play an important role in the prevention of dental caries, promoting the inhibition of demineralization and the increase of remineralization.

\section{CONFLICT OF INTEREST}

There are no potential conflicts of interest or any financial or personal relationships with other people or organizations that could inappropriately bias conduct and findings of this study.

\section{REFERENCES}

1. Maharani DA, Rahardjo A. Is the utilization of dental care based on need or socioeconomic status? A study of dental care in Indonesia from 1999 to 2009. Int Dent J. 2012;62:90-4.

2. Maharani DA. Do the Indonesians receive the dental care treatment they need? A secondary analysis on self-perceived dental care need. ISRN Dent. 2012;769809.

3. Amalia R, Schaub RMH, Widyayanti N, Stewart $\mathrm{R}$, Groothoff JW. The role of school-based dental program on dental caries experience in Yogyakarta Province, Indonesia. Int J Paediatr Dent. 2012;22:20310.

4. Hartono SWA, Lambri SE, Helderman WH. Effectiveness of primary school-based oral health education in West Java, Indonesia. Int Dent $\mathrm{J}$. 2002;52:137-43.

5. Maharani DA. Inequity in dental care utilization in the Indonesian population with a self-assessed need for dental treatment. Tohoku J Exp Med. 2009;218:229-39.

6. Vargas CM, Ronzio CR. Disparities in early childhood caries. BMC Oral Health. 2006; 6 Suppl 1:S3.

7. Bánóczy J, Petersen PE, Rugg-Gunn AJ. Milk fluoridation for the prevention of dental caries. World Health Organization. 2009.

8. Nohno K, Zohoori FV, Maguire A. Fluoride intake of Japanese infants from infant milk formula. Caries Res. 2011;45:486-93.

9. Arnold WH, Forer S, Heesen J, Yudovich KM, Steinberg D, Gaengler P. The in vitro effect of fluoridated milk in a bacterial biofilm - enamel model. Biomed Pap Med Fac Univ Palacky Olomouc Czech Repub. 2006:150;63-9.

10. Tamura EST, Ozawa T, Suzuki A, Saitoà YIT. Remineralization and acid resistance of enamel lesions after chewing gum containing fluoride extracted from green tea. Aust Dent J. 2011;56:394400.

11. Peckham S, Awofeso N. Water fluoridation: a critical review of the physiological effects of ingested fluoride as a public health intervention. Sci World J. 2014;293019.

12. Clark MB, Slayton RL. Fluoride use in caries prevention in the primary care setting. Pediatrics. 2014;134:626-633.

13. Ferrazzano GF, Cantile T, Quarto M, Ingenito A, Chianese L, et al. Protective effect of yogurt extract on dental enamel demineralization in vitro. Aust Dent J. 2008;53:314-9.

14. Krithikadatta J, Fredrick C, Abarajithan M, Kandaswamy D. Remineralisation of occlusal white spot lesion with a combination of $10 \%$ CPP-ACP and $0.2 \%$ sodium fluoride evaluated using Diagnodent: a pilot study. Oral Health Prev Dent. 2013;11:191-6.

15. Grande NM, Plotino G, Gambarini G, Testarelli L, D'Ambrosio F, et al. Present and future in the use of micro-CT scanner 3D analysis for the study of dental and root canal morphology. Ann 1st Super Sanita. 2012;48:26-34.

16. Hamba H, Nikaido T, Sadr A, Nakashima S, Tagami J. Enamel lesion parameter correlations between polychromatic Micro-CT and TMR. J Dent Res. 2012;91:586-91.

17. Liu BY, Lo ECM, Li CMT. Effect of silver and fluoride ions on enamel demineralization: a quantitative study using micro-computed tomography. Aust Dent J. 2012;57:65-70

18. Oshiro M, Yamaguchi K, Takamizawa T, Inage $H$, Watanabe T, Irokawa A, Ando S, Miyazaki M. Effect of CPP-ACP paste on tooth mineralization: an FESEM study. J Oral Sci. 2007;49:115-20.

19. He B, Huang S, Zhang C, Jing J, Hao Y, Xiao L, Zhou X. Mineral densities and elemental content in different layers of healthy human enamel with varying teeth age. Arch Oral Biol. 2011;56:997-1004.

20. Cho A, Suzuki S, Hatakeyama J, Haruyama N, Kulkarni AB. A Method for rapid demineralization of teeth and bones. Open Dent J. 2010;4:223-9.

21. Zhi QH, Lo ECM, Kwok ACY. An in vitro study of silver and fluoride ions on remineralization of demineralized enamel and dentine. Aust Dent J. 2013;58:50-6. 